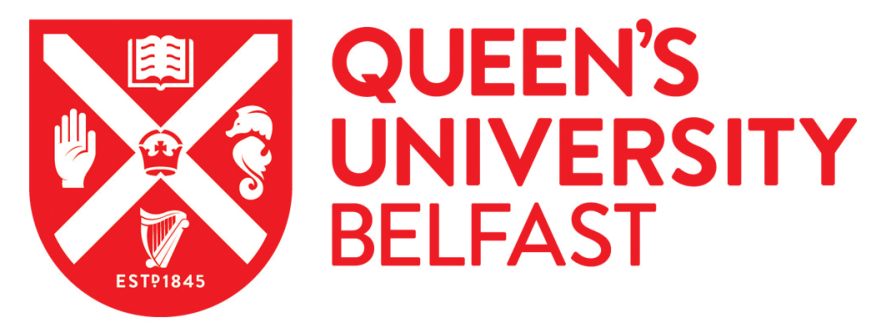

\title{
European style electoral politics in ethnically divided society: The case of Kosovo
}

Agarin, T., \& Wise, L. (2017). European style electoral politics in ethnically divided society: The case of Kosovo. Sudosteuropa, 65(1), 100-124. https://doi.org/10.1515/soeu-2017-0006

\author{
Published in: \\ Sudosteuropa
}

Document Version:

Peer reviewed version

Queen's University Belfast - Research Portal:

Link to publication record in Queen's University Belfast Research Portal

Publisher rights

(C) 2017 De Gruyter.

This work is made available online in accordance with the publisher's policies. Please refer to any applicable terms of use of the publisher.

\section{General rights}

Copyright for the publications made accessible via the Queen's University Belfast Research Portal is retained by the author(s) and / or other copyright owners and it is a condition of accessing these publications that users recognise and abide by the legal requirements associated with these rights.

Take down policy

The Research Portal is Queen's institutional repository that provides access to Queen's research output. Every effort has been made to ensure that content in the Research Portal does not infringe any person's rights, or applicable UK laws. If you discover content in the Research Portal that you believe breaches copyright or violates any law, please contact openaccess@qub.ac.uk. 


\title{
European style electoral politics in ethnically divided society: \\ The case of Kosovo
}

\author{
Laura Wise \& Timofey Agarin
}

\begin{abstract}
Our paper takes as its starting point the premise that elections are central moments in the life of polities: these are the times when individual citizens demonstrate support or otherwise of political institutions and regimes, assess their accountability and set agendas for the next government. In short, elections allow us to observe whether and how political regimes live up to society's expectations. This issue has particular resonance in deeply divided societies that have experienced ethnic conflict in the past. In the deeply divided society of Kosovo, local and national elections in 2013 and 2014 presented an opportunity to analyze voter choices and elite agendas, with the presence of ethno-political issues under scrutiny. Our paper concludes that the normalization of electoral politics, within the context of European aspirations, has not yet taken place in Kosovo, and that the options available to the electorate continue to be dominated by identity politicking.
\end{abstract}

Over the past 25 years, the region affected by the dissolution of the Federal Socialist Yugoslavia has seen content of political debate linked considerably to ethnic identity issues. This resulted in interethnic violence, emergence of ethnocentric nation-building projects, and centrifugal institutional politics. Following a long period of ethno-political gestation among Albanian-speakers, violence between the Albanian minority in southern Serbia and Serbian security forces, the war in Kosovo and particularly the NATO bombings in March 1999, Kosovo declared independence in 2008, supported by many Western states. Since then, the international community has maintained a large, although gradually diminishing, institutional presence in the country. The United Nations Mission in Kosovo (UNMIK) which governed immediately following the NATO intervention in 1999, was replaced in 2008 by the more technical and advisory European Union Rule of Law Mission (EULEX). Both missions were established with the intentions of democracy promotion, to foster democratic institutionbuilding and the empowerment of democratic political actors, as well as to contribute to the creation of favourable conditions for democratisation. ${ }^{1}$ However, the vision that eventual full executive powers would be transferred to Kosovo state institutions was delivered in a top-down manner from the European organisations through cooperation with domestic political elites.

Despite Kosovo's pursuit of fully recognized statehood, the status of the territory has remained contested by Serbia and much of the Serb majority residing in northern Kosovo. If anything, this points out the limitations of a narrow vision of democracy promotion, in part attested to the EU, and underlines the importance of elections and safeguarding political liberties. Indeed, some observers argue that though legitimizing new political institutions and

\footnotetext{
${ }^{1}$ Sonja GRIMM and Okka Lou Mathis, 'Stability First, Development Second, Democracy Third: The European Union's Policy towards the Post-Conflict Western Balkans, 1991-2010', Europe-Asia Studies 67, no. 6 (3 July 2015): 916-47.
} 
democratic political process via citizen participation at the ballot box, such an approach highlights the pivotal role of civil rights for all state citizens for meaningful participation in politics. As such, regular and competitive elections are simply not enough to usher in and normalize democratic politics in the absence of consensus about the beneficiaries of the democratic process. $^{2}$ The importance of Kosovo's status and administrative boundaries for Serb majority municipalities means that despite their overall size in the territory of Kosovo, issues of ethno-regional representation directly impact on policies of the new state, and at times directly challenge the notion that Kosovo citizenship is inclusive of all ethnic groups.

In this regard, Kosovo elections are paramount events in the life of the new democratic state, established with an immense international assistance. Holding of elections in post-conflict, deeply divided society is often less about the everyday issues of municipal governance, such as healthcare provision and education, and more as a test for the sustainability of political institutions. Although municipal elections were held in 2009 and parliamentary elections in 2010, the Serb community in the north of Kosovo boycotted both. Attempts to solicit Serb participation in Kosovo institutional structures have been made through the European Unionbrokered normalization dialogue between Pristina and Belgrade since 2010, which sought to resolve the issue of parallel governance of Kosovo's Serb majority municipalities supported by Belgrade, particularly in the Mitrovica North, Zvecan, Zubin Potok and Leposavic municipalities north of the River Ibar. This lead to the 'First agreement of principles governing the normalization of relations', known as the 'Brussels agreement', signed by both Kosovo and Serbia, which facilitates the participation of the Serb majority municipalities in local elections, and also provides for the formation of an Association/Community of Serb Municipalities (A/CSM) following successful local elections.

The significance of the Serb minority's participation, and the support that this had from the Serbian government in both the 2013 and 2014 elections demonstrates that the contests involved competition for ethnic votes. While society in Kosovo is still divided over understandings of state ownership and the direction of the nation-state building, the two elections we discuss in this paper hardly allow observers to see them as foundational moments in the functioning of Kosovo as a multi-ethnic democratic state. As the impact of ethnic issues in electoral campaigns is a widely used indicator in post-communist area studies, ${ }^{3}$ we hypothesize that in the context of different experiences of ethnic groups with political institutions and political leadership, the perceived effects of the European Union integration on the building of domestic institutions have not been delinked from ethnic politicking in electoral process. By scrutinizing the case of Kosovo, the main research question we ask addresses the existence of a correlation between levels of ethno-political mobilization and successful political entrepreneurs' capitalization of these agendas after the elections. Thus, our focus is on the impact of ethnic cleavage on the viability of electoral politics for both of the main ethnic groups in Kosovo, and we ascertain that any shift from group-based preferences affects the electorate's behavior in electoral politics in this young European democracy. As the ethnonational divide

\footnotetext{
2 Thomas Carothers, 'The End of the Transition Paradigm', Journal of Democracy 13, no. 1 (2002): 5-21.

${ }^{3}$ Daniel Bochsler, Territory and Electoral Rules in Post-Communist Democracies (Houndmills, 2010); Milada Anna VACHudova, Europe Undivided: Democracy, Leverage, and Integration After Communism. New York, 2005.
} 
dominated the debates and election outcomes in Kosovo, we spell out issues that have prevented the 'normalization' of electoral politics and allowed identities to comfortably dominate the background of all political deliberations.

\section{Democratization and State building in Divided Societies}

A classic political science argument says that a political system becomes institutionally democratic with the installation of competitive elections and multiple political parties. ${ }^{4}$ However, it remains incomplete until an overwhelming majority of the elected representatives unconditionally support democratic procedures, play by the rules of the democratic game and are accountable to all citizens of the state. ${ }^{5}$ Both the scholarly community and policy circles recognize that what political elites make of democratic institutions and institutional opportunity structures is a key component of what makes democracy work. ${ }^{6}$ Therefore, electoral politics reflect the process in which individual citizens partake in order to achieve specific outcomes, and are hard to imagine without their instrumental value, endorsing contenders' ability to shape the more hands-on, practical solution to individual preferences. ${ }^{7}$ The literature on electoral politics also makes clear that this multi-layered phenomenon is in place - and most often, likely to stay - not only because of political actors, but also because the electorate shape politics as both a normative and practical political process. ${ }^{8}$

Many scholars regard the unconditional institutionalization of democracy when candidates and, later, representatives principally decide and act on an issue, and not identity, basis to ensure their electoral success. ${ }^{9}$ On the other hand, the effectiveness of an electoral system based on levels of inclusion of multiple social cleavages, into policy making is particularly important in societies rigged by deep cleavages as well as in post-conflict conditions. ${ }^{10}$ Here, political representatives accountable to a narrowly defined electorate, be it regional, socioeconomic, or ethno-cultural groups, tend to import clientelist relations into the forum of political decision making and impede successful normalization of politics. ${ }^{11}$ This is particularly important as

\footnotetext{
${ }^{4}$ Robert A. DAHL, Polyarchy: Participation and Opposition (New Haven: Yale University Press, 1972).

${ }^{5}$ Ronald Inglehart and Christian Welzel, Modernization, Cultural Change, and Democracy: The Human Development Sequence. New York, 2005; Ronald IngleHART, Modernization and Postmodernization. Cultural, Economic, and Political Change in 43 Societies. Princeton, 1997.

${ }^{6}$ Gabriel A. Almond and Sidney VerbA, The Civic Culture. Political Attitudes and Democracy in Five Nations, Princeton, 1963; Harry ECKSTEIN, 'A Culturalist Theory of Political Change', American Political Science Review 82, no. 3 (1988): 789-804.

${ }^{7}$ Samuel H. BARNes et al., Political Action: Mass Participation in Five Western Democracies. London, 1979 , 197.

8 John MCGARRY and Brendan O’LEARY, 'Must Pluri-National Federations Fail?', Ethnopolitics 8, no. 1 (2009): 5-25.

${ }^{9}$ Russell J DALton, 'Communists and Democrats: Democratic Attitudes in the Two Germanies', British Journal of Political Science 24, no. 4 (1994): 469-93; William MisHLER and Richard Rose, 'Five Years After the Fall: Trajectories of Support for Democracy in Post-Communist Europe', in Critical Citizens: Global Support for Democratic Governance, ed. Norris Pippa. New York, 1999, 78-99.

${ }^{10}$ Elisabeth BAKKE and Nick SITTER, 'Why Do Parties Fail? Cleavages, Government Fatigue and Electoral Failure in the Czech Republic, Slovakia and Hungary 1992-2012', East European Politics, 8 May 2013, 1-18; Johanna Kristin BIRNIR, 'Divergence in Diversity? The Dissimilar Effects of Cleavages on Electoral Politics in New Democracies', American Journal of Political Science 51, no. 3 (2007): 602-19.

${ }^{11}$ Margit TAVITS, 'The Development of Stable Party Support: Electoral Dynamics in Post-Communist Europe', American Journal of Political Science, 2005, 283-98.
} 
democratizing political systems are more prone to crisis, and only those representatives committed to accountability to their segmented electorate are likely to survive electoral cycles in the democratic regimes. ${ }^{12}$

There is a broad agreement across studies of electoral politics that inclusion of interests of social, economic and ethno-cultural minority groups is essential for consolidation of democratic politics. ${ }^{13}$ Inclusion of all segments of the population is particularly important in the context of promoting and guaranteeing civil and political rights for all parts of the citizenry. Importantly, addressing social and economic inequalities in Central and Eastern European societies after the end of the communist regimes, has been central to addressing electorates' view of politics as a democratic process where rules of the game can be renegotiated. Though some have criticized the view that competition drives national agendas in electoral processes, ${ }^{14}$ most scholars agree that an ethnic security dilemma re-enforces boundaries between ethnic groups that spill over into the democratic political process. ${ }^{15}$ To this effect John Paul Lederach states that 'people, when threatened, seek security in narrower, more localized [ethnic or religious] identity groups, ${ }^{16}$ reducing the resources of non-dominant elites and motiving ethnopolitical mobilization to central authorities.

However, the earlier hopes of a gradual conversion of electoral politics in the postcommunist region with those observed in the more established democracies, have failed to materialize. Across ethnically divided post-communist societies, levels of ethno-political mobilization remain high and political parties continue to galvanize electorates by talking up the issues of perceived difference in rights and opportunities of ethnic groups. We therefore need to ask ourselves, whether the post-communist condition per se, or a more narrow set of factors, such as ethnic division of societies, volatility of electoral politics, and unresolved claims to scarce political and socioeconomic resources of the state have prevented the 'normalization' of electoral politics in ethnically divided societies. Throughout the postcommunist history, ownership over institutions of the state has been contested and re-designed to be exclusive to serve best the culturally-distinct peoples seeking self-determination. ${ }^{17}$

\footnotetext{
${ }^{12}$ Aleksandra ZDEB, 'Prud and Butmir Processes in Bosnia and Herzegovina: Intra-Ethnic Competition from the Perspective of Game Theory', Ethnopolitics (ahead-of-print, 18 February 2016), doi:10.1080/17449057.2016.1143661; Boyka STEFANOVA, 'Ethnic Nationalism, Social Structure, and Political Agency: Explaining Electoral Support for the Radical Right in Bulgaria', Ethnic and Racial Studies 32, no. 1 (2009): 1-23; Zoe LEFKOFRIDI, Markus Wagner, and Johanna E. Willmann, 'Left-Authoritarians and Policy Representation in Western Europe: Electoral Choice across Ideological Dimensions', West European Politics (ahead of print): 1-26.

${ }^{13}$ Simon HIX, 'Elections, Parties and Institutional Design: A Comparative Perspective on European Union Democracy', West European Politics 21, no. 3 (1998): 19-52; Kris Deschouwer, 'The Decline of Consociationalism and the Reluctant Modernization of Belgian Mass Parties', How Parties Organize: Change and Adaptation in Party Organizations in Western Democracies, 1994, 80-108.

${ }^{14}$ Susan OlzaK, The Dynamics of Ethnic Competition and Conflict. Stanford, 1992; Susan OlzaK, The Global Dynamics of Racial and Ethnic Mobilization. Stanford, 2006.

${ }^{15}$ Barry R. Posen, 'The Security Dilemma and Ethnic Conflict', Survival 35, no. 1 (1993): 27-47; Paul RoE, 'The Intrastate Security Dilemma: Ethnic Conflict as a Tragedy'?' Journal of Peace Research 36, no. 2 (1999): 183-202.

${ }^{16}$ John Paul LederAch, Building Peace: Sustainable Reconciliation in Divided Societies. Washington, 1997, 18.

${ }^{17}$ Michael Hechter, 'Containing Nationalism', Social Forces 79, no. 3 (2001).
} 
We do not see ethno-political mobilization of non-dominant groups in emerging democracies as an 'intoxicating brew, leading in case after case to ill-conceived wars.' ${ }^{18}$ More to the point, Mark Bessinger claims that ethno-nationalism might have a positive effect on democratization when non-dominant groups mobilize against outright disempowerment and side-lining in democratic politics, hence aiding democratic process. ${ }^{19}$ This observation has informed Andreas Wimmer et al to suggest that non-dominant ethnicities are more likely to engage in open conflict with a democratizing state than with any other non-democratic regime. ${ }^{20}$ Thus, including minority representatives in political decision-making allows for disputes over the remit of minority participation in political process to become an adequate component of electoral politics, rather than a reason to resort to interethnic strife and violence.

Donald Horowitz' Ethnic groups in conflict suggests that multiple ethnic groups threaten to derail democratization because identity determines the 'distribution of important material and nonmaterial goods. ${ }^{21}$ Though divided societies are not unsuited for democratic electoral politics, nepotism, ${ }^{22}$ lower organizational $\operatorname{costs}^{23}$ and economic inequalities ${ }^{24}$ all have positive impacts on ethno-political mobilization. Thus unsurprisingly, Horowitz argues that majoritarian or minority rule might be detrimental to establishing a representative democracy as voters are likely to make choices of political representatives from their ethnic ilk, and this holds for both the initiation of and maintaining the democratization dynamics. Wimmer et al however make an important corrective to claims of ethnic origins of conflicts in democratizing states. ${ }^{25}$ Paying attention to the 'configuration of power' and avenues available to different groups to access and participate in political institutions, to share power effectively distinguishes pathways for democratic consolidation.

Since Arendt Lijphart's description of the most effective mechanisms for governing divided societies, 'power-sharing' has been the popular recipe for making political entrepreneurs of contending groups cooperate. ${ }^{26}$ As in many cases across the globe, including Northern Ireland, Bosnia and Herzegovina, and Iraq, consociationalist arrangements have been put into practice when designing constitutional futures of divided post-conflict societies. Though Lijphart's

\footnotetext{
${ }^{18}$ Edward MANSFIELD and Jack SNYDER, 'Democratization and the Danger of War', International Security 20 , no. 1 (1995): 5-38.

${ }^{19}$ Mark R. BEISSINGER, ‘A New Look at Ethnicity and Democratization', Journal of Democracy 19, no. 3 (2008): 85-97.

${ }^{20}$ Andreas Wimmer, Lars-Erik Cederman, and Brian Min, 'Ethnic Politics and Armed Conflict: A Configurational Analysis of a New Global Data Set', American Sociological Review 74, no. 2 (2009): 316 -37. Lars-Erik Cederman, Andreas Wimmer, and Brian Min, 'Why Do Ethnic Groups Rebel? New Data and Analysis', World Politics 62, no. 1 (2010): 21.

${ }^{21}$ Donald L. Horowitz, 'Democracy in Divided Societies', in Nationalism, Ethnic Conflict, and Democracy, ed. Larry DIAMOND and Marc F. PLATTNER. London, 1994.

22 Tatu VANHANEN, 'Domestic Ethnic Conflict and Ethnic Nepotism: A Comparative Analysis', Journal of Peace Research 36, no. 1 (1999): 55-73.

${ }^{23}$ Nicholas SAmBANIS, 'Do Ethnic and Nonethnic Civil Wars Have the Same Causes? A Theoretical and Empirical Inquiry (Part 1)', Journal of Conflict Resolution 45, no. 3 (2001): 259-82.

${ }^{24}$ Demet Yalcin MoussEAU, 'Democratizing with Ethnic Divisions: A Source of Conflict?', Journal of Peace Research 38, no. 5 (2001): 547-67.

${ }^{25}$ Wimmer, CeDerman, and Min, 'Ethnic Politics and Armed Conflict: A Configurational Analysis of a New Global Data Set'.

${ }^{26}$ Arend LiJPHART, 'Unequal Participation: Democracy’s Unresolved Dilemma', The American Political Science Review 91, no. 1 (1997): 1-14.
} 
early works see 'culturally divided' societies as the object of political engineering, contemporary prophets of consociationalism John McGarry and Brendan O'Leary point out that ethnic identities are distinct from those chosen in electoral politics and underlying the system of political representation. ${ }^{27}$

It is a more fluid view of identity that anticipates an increased interaction and eventual retreat of identities from politicking. ${ }^{28}$ Yet in a political process that forces citizens to rankorder their choices among different candidates on the ballot paper, 'political and social organizations founded on ethnic belonging rather than on individual choice' have barely succeeded in managing ethnic conflict. ${ }^{29}$ As a result polities operating on the basis of powersharing exacerbate ethnic cleavages in divided post-conflict societies. ${ }^{30}$

Unsurprisingly therefore, Wimmer et al see ethnic exclusion in politics as one of the main drivers of ethnic conflict. ${ }^{31}$ When political structures provide little opportunity for participation and limited space for nonviolent pursuit of goals for political entrepreneurs of non-dominant groups, we are indeed very likely to see entrenchment of 'tribal politics' in democratic electoral processes. $^{32}$ Timothy Sisk further claims that however no matter how democratic political procedures are, simple majority rule is badly suited for institutional change and does not bid well for democratic stability, resulting in mobilization of non-dominant groups. ${ }^{33}$ Wolfgang Merkel and Brigitte Weiffen further refine this argument by analyzing third wave democracies, concluding that political institutions, alongside principles and procedures of the new political regime, help to inscribe intergroup equality into the fabric of electoral politics in the newly democratizing states, and make democratic consolidation possible even in the most heterogeneous societies. ${ }^{34}$

Ominously, Richard Rose and William Mishler proclaimed that post-communist publics value democracy not for what it is, but rather for what it is not. ${ }^{35}$ Looking into the details of the 2013 municipal as well as the 2014 Assembly elections in Kosovo will allow us to assess the degree of ethnic politicking and clientelism in electoral politics in this country. Probing deeper into discourses preceding the elections and focusing on preferences of elected politicians, we are able to identify what different ethnic segments in Kosovo society favor in this new democracy, and what they do not.

\footnotetext{
${ }^{27}$ John McGARRY and Brendan O'LEARY, The Politics of Ethnic Conflict Regulation: Case Studies of Protracted Ethnic Conflicts. Abingdon, 2013.

${ }^{28}$ Beáta HUZKA, 'Framing National Identity in Independence Campaigns: Secessionist Rhetoric and Ethnic Conflict', Nationalism and Ethnic Politics 20, no. 2 (2014): 153-73.

${ }^{29}$ Marc Morjé HowARD, The Politics of Citizenship in Europe. New York, 2009.

${ }^{30}$ Melani CAMMETT and Edmund MALESKY, 'Power Sharing in Postconflict Societies: Implications for Peace and Governance', Journal of Conflict Resolution 56, no. 6 (2012): 982-1016.

${ }^{31}$ Cederman, Wimmer, and Min, 'Why Do Ethnic Groups Rebel? New Data and Analysis'.

${ }^{32}$ LEDERACH, 'Building Peace: Sustainable Reconciliation in Divided Societies'.

33 Anna K. JARSTAD and Timothy D. Sisk, From War to Democracy: Dilemmas of Peacebuilding. New York, 2008.

${ }^{34}$ Wolfgang MERKEL and Brigitte WEIFFEN, 'Does Heterogeneity Hinder Democracy?', Comparative Sociology 11, no. 3 (2012): 387-421.

${ }^{35}$ William MiSHLER and Richard Rose, 'Five Years After the Fall: Trajectories of Support for Democracy in Post-Communist Europe', in Critical Citizens: Global Support for Democratic Governance, ed. Norris Pippa (Oxford: Oxford University Press, 1999), 78-99.
} 


\section{Dynamics in politics and the importance of elections}

Citizens of post-communist states had lifelong experience of undemocratic rule prior to the break-up of communist regimes, and many of them remain attached to the mind-set of the earlier however authoritarian, yet at all times undemocratic, regimes. ${ }^{36}$ Yet in view of the importance of opportunities opened after the start of the democratic transition, preferences for political participation in decision-making among publics should not be equated with unconditional or unwavering pursuit of collective good. ${ }^{37}$ Some of these same phenomena have been observed in divided societies, particularly as tantamount to support of ethnic clientelism.

Support for democracy is often believed to reflect the psychologically loose attachment citizens have to the positive symbols of democracy, such as sovereignty over territory and selfdetermination of its peoples. Citizens of new democracies assess the new political regime in which they find themselves by not only, or rather not mainly, estimating favorable democratic ideals and practices they experience. Little experience and limited sophistication of the workings of democratic politics are found to make participation in the political process driven by uncertainty over whether democracy or any other political regime offers satisfying solutions to the many problems facing societies. Under such uncertainty, citizens who are democratic novices often embrace both democratic and authoritarian political propensities concurrently, and participation in democratic politics does not necessarily mean rejection of authoritarianism or vice versa. ${ }^{38}$

With these dynamics in mind, our main research question addresses the existence of a correlation between levels of ethno-political mobilization and successful political entrepreneurs' capitalization of these agendas after the elections. ${ }^{39}$ Overall, findings on this link will allow for a qualified statement on the 'normalization' of electoral politics in ethnically divided societies in particular, and the impact of ethno-political cleavages on the process of democratization in general. ${ }^{40}$ More broadly, we will be able to conclude whether political processes and electoral politics in post-conflict societies have a similar impact on support for democracy as an ideal form of regime as had been previously demonstrated in other countries. ${ }^{41}$

\footnotetext{
${ }^{36}$ William MishLER and Richard Rose, 'Learning and Re-Learning Regime Support: The Dynamics of PostCommunist Regimes', European Journal of Political Research 41, no. 1 (2002): 5-36.

${ }^{37}$ Ada W. FINIFTER and Ellen MICKIEWICZ, 'Redefining the Political System of the USSR: Mass Support for Political Change', American Political Science Review 86, no. 4 (1992): 857-74.

${ }^{38}$ Marta LAGOS, 'Between Stability and Crisis in Latin America', Journal of Democracy 12, no. 1 (2001): 137 45; Richard Rose, Doh C. ShIn, and Neil Munro, 'Tensions Between the Democratic Ideal and Reality: South Korea', Critical Citizens: Global Support for Democratic Government, 1999, 146-65.

${ }^{39}$ Carsten Jensen and Svend-Erik SkAANING, 'Modernization, Ethnic Fractionalization, and Democracy', Democratization 19, no. 6 (2011): 1117-37; Jørgen MølLER and Svend-Erik SKAANING, 'Beyond the Radial Delusion: Conceptualizing and Measuring Democracy and Non-Democracy', International Political Science Review 31, no. 3 (2010): 261-83.

${ }^{40}$ John D. MCCARThY, Jackie SMITH and Mayer N. ZALD, 'Accessing Public, Media, Electoral, and Government Agendas', ed. Doug McADAM and Mayer N. ZALD. John D. McCARTHY (Cambridge: Cambridge University Press., 1999); John T. IsHIYAMA, 'Founding Elections and the Development of Transitional Parties: The Cases of Estonia and Latvia, 1990-1992', Communist and Post-Communist Studies 26, no. 3 (1993): 277-99.

${ }^{41}$ Samuel H. Barnes and Janos Simon, Popular Conceptions of Democracy in Postcommunist Europe. Budapest, 1998; Bryan D. SILVER and Kathleen M. Dowley, 'Measuring Political Culture in Multiethnic Societies: Reaggregating the World Values Survey', Comparative Political Studies 33, no. 4 (2000): 517-50;
} 
The working hypothesis is that high level of commitment to ethno-political mobilization is associated with low levels of normalization of electoral politics and high support for ethnopolitical rhetoric.

Yet at a more fundamental level, post-communist societies historically have had low levels of trust in politicians, political institutions and have been reluctant to participate in any kind of political activity, including elections. There has been one notable exception to this rule: where concerns for ethnic identity have formed a strong motivation to forge political alliances these regularly bring citizens to the ballot box. Particularly in ethnically divided and post-conflict societies, social and political cleavages between ethnic segments of electorate are often effectively reframed to attract electoral support and ensure stable political alliance during the electoral cycles. The resulting landscapes of electoral politics witnesses a perceptible shift towards political parties capitalizing on ethnic, rather than social, cleavages and fostering political rhetoric that mobilizes ethnic electorate. The literature on ethnically divided societies makes clear that once incentives are in place for political representatives to cater exclusively for ethnic constituencies, forging political alliances to bridge the ethnic divide becomes extremely difficult. ${ }^{42}$ Furthermore, higher levels of political salience, expressed differences in cultural markers and deeper differences of group experiences in the past, makes it more difficult for the electorate to re-align expectations from their political representatives in post-conflict societies.

This evolution runs against the grain of electoral politics in Western European democracies and across much of the EU, which is leading post-conflict reconstruction, and overseeing state building in the states of the Western Balkans. Two states in the Western Balkans, Bosnia \& Herzegovina and Kosovo, have a unique dynamic in electoral party politics, particularly where success in political reform is connected to the prospect of the EU membership. The prospect is ever more pertinent since societies in these states maintain several social axes, including ethnicity and language, and spectrums of winners and losers of transition. Previously, much attention has been given to electoral politics in post-conflict societies with analysis from the point of view of consolidation. However, few have analyzed electoral politics using the perspective of divided societies and none through the focus on crucial points in the life of democracies, the election, to signpost the abatement of, if not the normalization in, ethnic politicking.

We have chosen Kosovo as a country case, because a range of comparative and longitudinal research on democratization, role of parties and politicization of identities demonstrates high volatility in terms of political stability and ethnic politicking in this country. ${ }^{43}$ This is despite

\footnotetext{
Bernhard Wessels and Hans-Dieter KlingEMANN, 'Parties and Voters-Representative Consolidation in Central and Eastern Europe?', International Journal of Sociology 36, no. 2 (2006): 11-44.

${ }^{42}$ Adrian Guelke, Democracy and Ethnic Conflict: Advancing Peace in Deeply Divided Societies. Basingstoke, 2010.

${ }^{43}$ Fred CocozzelLI, 'Between Democratisation and Democratic Consolidation: The Long Path to Democracy in Kosovo', Perspectives on European Politics and Society, 2013, 1-19; Karin DYRSTAD, 'Does Civil War Breed Authoritarian Values? An Empirical Study of Bosnia-Herzegovina, Kosovo and Croatia', Democratization 20, no. 7 (2013): 1219-42; Denisa Kostovicova, Mary Martin, and Vesna BojiciC-Dzelilovic, 'The Missing Link in Human Security Research: Dialogue and Insecurity in Kosovo', Security Dialogue 43, no. 6 (2012): 569-85; Gëzim KRASNIQI, 'Equal Citizens, Uneven Communities: Differentiated and Hierarchical Citizenship
} 
the widespread involvement of the EU and international organizations in developing the democratic hardware in the country and sponsoring, by a variety of means, the effective installation of democratic software with its political elites.

\section{Electoral Study: Local Elections in Kosovo}

The 2013 local elections for municipal mayors and assembly members cannot be understood independently of the circumstances in which Kosovo became a political entity. Successful execution of municipal elections in all 38 municipalities was anticipated as an indicator for confidence in the government's ability to conduct democratic processes across the entire territory, and the development of Kosovo as a democratic, multi-ethnic state. Furthermore, the participation of Serbs parties and voters, facilitated in northern municipalities by Organisation for Security and Cooperation in Europe (OSCE), was sought as an output of the Pristina-Belgrade normalization process, and an implemented provision of the Brussels Agreement. Widespread Serb participation was also anticipated as a minority endorsement for forming a decentralized body, the Association/Community of Serb Municipalities (A/CSM), which was also an agreed provision in the Brussels Agreement and would increase the degree of ethnic decentralization in Kosovo, whilst bringing the Northern municipalities into the fold ${ }^{44}$ Minority Serb ethnic parties in Mitrovica North, Leposavic, Zvecan and Zubin Potok municipalities, had consistently resisted previous attempts by international actors to integrate the north into Kosovo institutions, and boycotted all elections held in Kosovo since its independence. ${ }^{45}$ This prospective electoral mobilization meant that the participation of minority ethnic parties, and the mechanisms of facilitating this, became a divisive ethno-political issue among representatives of both majority and minority parties throughout the campaign.

Positions of ethno-political entrepreneurs and their election campaigns, particularly regarding issues of ethnic inclusion, minority participation, and ownership of institutions, can be examined through the lens of ethnic majority and minority parties, and focused on parties appealing to the majority ethnic community (Albanians), and the numerically largest minority (Serbs), although ethnic parties representing members of Bosniak, Roma, Gorani, Ashkali, Egyptian and other communities also competed. The reasons for this analytical division are twofold. Firstly, almost all candidates adhered to ethnic cleavage by appealing exclusively to their ethno-linguistic communities, using mono-lingual media channels to communicate with voters. ${ }^{46}$ Secondly, majority and minority parties postured themselves in an outbidding

\footnotetext{
in Kosovo', Ethnopolitics 14, no. 2 (2015): 197-217; Janine Natalya ClaRK, 'Kosovo’s Gordian Knot: The Contested North and the Search for a Solution', Nationalities Papers 42, no. 3 (2014): 526-47.

${ }^{44}$ First agreement of principles governing the normalization of relations, RTS.rs, 20 April 2014, http://www.rts.rs/upload/storyBoxFileData/2013/04/20/3224318/Originalni $\% 20$ tekst $\% 20$ Predloga $\% 20$ sporazum a.pdf

${ }^{45}$ Ivana BOZIC, Dina MILANOVIC, Milos STANOJKOVIC, Kosovo Parliamentary Elections 2014: Serb community toward new political realities, Konrad Adenauer Stiftung Policy Briefs Kosovo, June 2014, http://www.kas.de/kosovo/en/publications/38002/

${ }^{46}$ European Union Electionn Observation Mission, Preliminary Statement: A Positive Step Forward for Democracy in Kosovo, 5 December 2013, http://www.eueom.eu/files/pressreleases/english/preliminarystatement-in-kosovo-05112013 en.pdf
} 
process against co-ethnic parties when either criticising the record of their competitors, or making claims about minority governance issues.

Majority, ethnic-Albanian, party campaigning over identity issues prior to the election promulgated the following concerns: facilitation of minority voting; integration of the Serb minority through institutional design; and the influence of external governments over minority parties, namely Serbia. Throughout the campaign for the Albanian vote, parties posited themselves along a spectrum of those parties supportive of Serb participation in the electoral process and subsequent institutions, and those who vehemently opposed any steps to encourage minority voter turnout.

On the facilitation of the election in Serb majority municipalities, and participation of Serb ethnic parties, the most moderate campaign was run by the centre-right Democratic Party of Kosovo (PDK), the incumbent party led by Prime Minister Hashim Thaci. Whether out of genuine conviction for a multi-ethnic, inclusive Kosovo, or as a pragmatic choice to assist the pursuit of EU integration due to pressure from international actors, the PDK made repeated public appeals for Serbs to participate in local elections. ${ }^{47}$ Representatives of the centre-right Democratic League of Kosovo (LDK) joined with other opposition parties to condemn the proposed visits by members of the Serbian government, such as the then-Prime Minister Ivica Dacic, to Serb majority municipalities during the election campaign, arguing that this violated both regulations on political visits during the campaign period, and Kosovo's sovereignty. ${ }^{48}$ This differed to the PDK, who publically welcomed the visit as an opportunity to encourage Serbs to vote. ${ }^{49}$ The use of status-neutral ballots in the northern municipalities - an important pre-requisite for Serb voters - and visits of some Serbian officials to Kosovo, were vocally opposed by the self-determination movement Vetevendosje (VV), who claimed that both violated the constitution, and showed that the elections were being conducted on Serbia's terms, thus threatening Kosovo's sovereignty. ${ }^{50}$

Minority participation in Kosovo institutions, such as forming the decentralized Association/Community of Serb Municipalities (A/CSM), was another identity-framed concern around which some Albanian ethnic parties mobilized. As Thaci was a signatory to the Brussels Agreement, and the PDK had previously formed governing coalition with the Serb-minority Independent Liberal Party (SLS) under Kosovo's power-sharing constitution, the PDK was comparatively distinguished to majority voters as being in favour of minority integration, particularly as statements were disseminated through Albanian-language and international media outlets. However, other members of the PDK and members of the Alliance

\footnotetext{
${ }^{47}$ Peter GEOGHEGAN, Kosovo PM urges Serbs to vote in make-or-break elections, The Guardian, 14 November 2013, http:/www.theguardian.com/world/2013/nov/14/kosovo-pm-hashim-thaci-serbs-voteelections; UNMIK Headlines, Thaçi: Elections, European test for Kosovo (Zëri), UNMIK Media Monitoring, 8 October 2013, http://media.unmikonline.org/?p=26041; UNMIK Headlines, Thaci calls on Serbs to take part in elections (dailies), UNMIK Media Monitoring, 12 October 2013, http://media.unmikonline.org/?p=26385 ${ }^{48}$ UNMIK Headlines, Opposition against Dacic's visit (Epoka e Re), UNMIK Media Monitoring, 11 October 2013, http://media.unmikonline.org/?p=26300

${ }^{49}$ UNMIK Headlines, Thaçi rejects Edita, hails Dacic's messages (Koha Ditore), UNMIK Media Monitoring, 22 October 2013, http://media.unmikonline.org/?p=26385

${ }^{50}$ KIPRED, Local Elections of 2013 in Kosovo: General Overview and Recommendations on Electoral Reform, KIPRED Policy Paper, March 2014, http://www.kipred.org/en/news/Local-Elections-in-Kosovo-2013Overview-and-recommendations-for-electoral-reform-252
} 
for the Future of Kosovo (AAK) made negative public statements about their support for both the agreement and attempts to integrate the northern municipalities. ${ }^{51}$ The most explicitly ethnic claims prior to the voting period were made by VV, who consistently opposed the Brussels Agreement and decentralization based on ethnicity, repeatedly arguing that the normalization process and concessions to minorities were creating a separate Serb entity in Kosovo, rather than integrating the northern municipalities. ${ }^{52}$ Despite their opposition to an agreement which facilitated the municipal elections, VV fielded candidates in almost all municipalities, in order to increase their power base outside of the parliament. ${ }^{53}$

Mobilization of minority Serb ethnic parties, and the election campaign in Serb majority areas, was divided between parties which advocated voter turnout, Serb integration, and decentralization, as ways of protecting minority interests and continued habitation of Serbs in Kosovo, and an boycott movement, who violently opposed holding the election in the north, as a threat to the Serbian-supported parallel institutions in those municipalities. Parties who supported minority electoral participation were further split between those materially backed by the Serbian government (Citizen's Initiative Serbian - G.I. Srpska) and parties who had stood in previous Kosovo elections. All of their campaigns were run on an identity, rather than issue, basis, although fears of losing parallel structures in the north was driven in part by material fears of losing employment and subsidies provided by the Serbian state.

Open and preferential treatment of G.I. Srpska by the Serbian government meant that it dominated the campaign for Serb votes. The party was dogged by accusations of being a proxy for Serbia's territorial claims over Kosovo, ${ }^{54}$ and of hoping to form the Association/Community of Serb Municipalities (A/CSM) as a disruptive federal entity, replicating Republika Srpska's behaviour in Bosnia-Herzegovina. ${ }^{55}$ There were also widespread allegations of intimidation towards Serbs, particularly in Partes and Strpce, to vote for G.I. Srpska, or worsening welfare as a result of severed economic support from the Serbian state. ${ }^{56}$ G.I. Srpska's campaign revolved around negatively mobilizing Serbs to vote across Kosovo in order to block Albanian candidates from winning mayoral and deputy seats in Serb majority areas, which did nothing to challenge Albanian claims that participation of Serbs in the election threated Kosovo's sovereignty, especially when these calls were echoed by Serbian

\footnotetext{
${ }^{51}$ UNMIK Headlines, Haradinaj: Thaçi and I talked about the north (Koha Ditore), UNMIK Media Monitoring, 17 September 2013, http://media.unmikonline.org/?p=24644; UNMIK Headlines, Kuçi: Serbia's campaign in Kosovo will not be allowed (Koha), UNMIK Media Monitoring, 7 October 2013, http://media.unmikonline.org/?p=25745

${ }^{52}$ UNMIK Headlines, Kurti: Kosovo, Republic of minority (Koha Ditore), UNMIK Media Monitoring, 16 September 2013, http://media.unmikonline.org/?p=24560; Vetevendosje, Ratification of Serbia's Authority in Kosovo, Vetevendosje News English, 28 June 2013, http://www.vetevendosje.org/en/news_post/ratification-ofserbias-authority-in-kosovo-4/; Levizja Vetevendosje, The manifesto principles and priorities of Lëvizja VETËVENDOSJE!: 100 points joined together by the changes necessary for Kosova, September 2013, http://www.vetevendosje.org/wp-content/uploads/2013/09/Programi i shkurte anglisht.pdf, 6

${ }^{53}$ BRAJSHORI / TËRNAVA, The Republic of Kosovo's 2013 Local Elections Handbook, 22.

${ }^{54}$ KIPRED, Local Elections of 2013 in Kosovo, 10

${ }^{55}$ Marko PRELEC, Something Completely Different in Northern Kosovo, Balkans Policy Research Group, 23 October 2013, http://balkansgroup.org/publications/test/, 2

${ }^{56}$ Edona PECI, Kosovo Prosecutors Probe Serbian List for Poll Abuses, Balkan Insight, 26 November2013 http://www.balkaninsight.com/en/article/kosovo-prosecution-investigates-serbian-backed-srpska; PRELEC, Something Completely Different in Northern Kosovo, 8
} 
government officials. ${ }^{57}$ Campaigning on a more positive-integrationist platform was the Independent Liberal Party (SLS), who, as mentioned had already served as a minority coalition member in the Kosovo government, and had a record of participating in Kosovo institutions. The Serbian, Democracy and Justice (GI-SDP) also mobilised around supporting Serb integration, but they claimed that participation was possible without recognising Kosovo's independence, ${ }^{58}$ aligning with G.I. Srpska's strategic integration approach.

The most extreme Serb mobilization against the elections was orchestrated by a boycott movement in the north, who used sabotage of election materials and intimidation tactics to dissuade Serbs from voting. They argued that to participate would legitimize Pristina's rule, effectively end parallel structures of governance from Belgrade in the north, and therefore cede the four municipalities to Kosovo. ${ }^{59}$ As stated by one Serb official in Mitrovica North, "no one here wants Kosovo institutions. We who boycott hope the Serbian institutions will survive, and the ones who vote hope that they will keep Serbian institutions that way."

Turnout across Kosovo was $39.95 \%,{ }^{61}$ an encouraging result for those hoping to prove that Kosovo could successfully conduct elections with minimal support from the international community, as the elections were organised by Kosovo's Central Election Commission, aside from the OSCE's facilitation of elections in the four northern municipalities, In three of the Serb majority municipalities in the north, turnout was far lower, at $25.6 \%,{ }^{62}$ and a re-run was required at 30 polling stations. This was due to violent attacks on several polling stations on election day, when masked men threatened voters, destroyed and stole ballot boxes, forcing the vote to be suspended. ${ }^{63}$ Voting was repeated at three polling stations in Zvecan and 27 polling stations in Mitrovica North on November 17, 2013. ${ }^{64}$ Meanwhile the high turnout in other Serb majority municipalities south of the Ibar was unprecedented, averaging $59.15 \% .{ }^{65}$ The turnout for the re-run in Mitrovica North on the $17^{\text {th }}$ of November remained stable, despite the risk of repeated violence from those opposed to the elections. This level of participation in Serb majority municipalities is significant, due to the risk of intimidation for citizens who turned out to vote for a second time. In addition to these re-runs, the second rounds of voting were held

\footnotetext{
${ }^{57}$ Peter GEOGHEGAN, Kosovo Serbs head to the polls - again, Deutsche Welle, 7 November 2013, http://www.dw.com/en/kosovo-serbs-head-to-the-polls-again/a-17211698; B92, Dačić calls on Serbs to vote in local elections in Kosovo, 21 October 2013, http://www.b92.net/eng/news/politics.php? yyyy=2013\&mm $=10 \& \mathrm{dd}=21 \&$ nav $\mathrm{id}=88059$

${ }^{58}$ UNMIK Headlines, Ivanovic: Yes to elections, no to statehood (Tribuna), UNMIK Media Monitoring, 9 September 2013, http://media.unmikonline.org/?p=24204

${ }^{59}$ B92, KM: Miting za bojkot izbora, B92, 17 September 2013, http://www.b92.net/info/vesti/index.php?yyyy=2013\&mm=09\&dd=17\&nav_id=754705

${ }^{60}$ PRELEC, Something Completely Different in Northern Kosovo, 2

${ }^{61}$ General Statistics, Republic of Kosovo Central Election Commission, Pristina 2013, http://www.kqzks.org/en/news/Details/153

${ }^{62}$ Adrian ZEQIRI / Lars BUREMA / Jérémie ZEITOUN, Kosovo Local Elections 2013: Lessons Learnt for Minority Communities, Pristina, European Centre for Minority Issues Kosovo, 19 December 2013, http://www.ecmikosovo.org/?p=4322, 2

${ }^{63}$ European Union Election Observation Mission, Preliminary Statement: A Positive Step Forward for Democracy in Kosovo, 5 December 2013, http://www.eueom.eu/files/pressreleases/english/preliminarystatement-in-kosovo-05112013 en.pdf

${ }^{64}$ European Union Election Observation Mission, Preliminary Statement.

${ }^{65}$ Statistics By Municipality, Republic of Kosovo Central Election Commission, Pristina 2013, http://www.kqzks.org/en/news/Details/153
} 
in 25 of the 38 municipalities on the $1^{\text {st }}$ of December, to determine mayoral results, most of which were conducted peacefully. ${ }^{66}$

The elections saw a number of incumbents unseated, with the PDK, LDK, and the AAK all losing some municipalities. Although the PDK won the largest number of mayoral seats and members of municipal councils, they lost several mayoral seats to the LDK in the second round, with this result interpreted as an anti-PDK vote, rather than support for LDK policies. ${ }^{67}$ Vetevendosje unseated the LDK's mayor in Pristina, marking their increasing popularity in recent years as a protest movement. ${ }^{68}$ These results could suggest that whilst the local election campaigns were dominated by ethno-political rhetoric and identity claims over institutions, a portion of electorate chose to hold the PDK to account for their dire record on employment, economic growth, and corruption.

In the Serb-majority municipalities, Belgrade's support for the G.I. Srpska paid off, with the list winning the highest number of councilor seats than any other competitors, and the mayoral seats of nine municipalities. ${ }^{69}$ Although this result was positive for both the Serbian and Kosovo governments, as it demonstrated Belgrade's commitment to the implementation of aspects of the Brussels agreement, G.I. Srpska's alleged corrupt and unfair campaign practices raises the question of Serbia's commitment to democratically and transparently facilitating local decision-making over the mandates of both the agreement and the Association/Community of Serb Municipalities (A/CSM). However, the significant turnout of voters across Serb municipalities in the presence of insecurity can be interpreted as preliminary acceptance of the Brussels agreement and the future of their participation within institutional structures of Kosovo by parts of the Serb community, for a plurality of reasons, and the boycott movement's failure to maintain the status quo of parallel governance. The seriousness of violent intimidation, however, and the theft of ballot boxes and voter lists, should not be underestimated, as citizens' ability to cast their vote safely and confidentially is a core standard for successful, free and fair elections, something which was not guaranteed for voters in the north.

Fears over the nature of the Association/Community of Serb Municipalities (A/CSM) continued to dominate public debate, particularly as it was due to be formed in December 2013, dependant on Serb participation in the local polls. These concerns were stoked by statements by the G.I. Srpska mayor-elect of Mitrovica North, Krstimir Pantic, who declared that "We have won nine municipalities, where Serb citizens will never recognise the independence of Kosovo" ${ }^{70}$ In January he refused to sign the mayoral pledge due to the use of Kosovo state symbols on the document, which he claimed violated the status neutral requirement of the

\footnotetext{
${ }^{66}$ Preliminary Results from Kosovo Runoff Bring Surprises, Radio Free Europe, 2 December 2013, http://www.rferl.org/content/kosovo-election-runoffs-surprises/25187158.html

${ }^{67}$ Leon MALAZOGU / Ngadhnjim HALILAJ / Rezarta DELIBASHZADE, Election Trends 2000-2014: A Numerical Analysis of Participation and Representation, Democracy for Development Institute, July 2015, http://d4d-ks.org/punimet/election-trends-2000-2014-a-numerical-analysis-of-participation-andrepresentation/?lang=en, 53

${ }^{68}$ Leon MALAZOGU / Ngadhnjim HALILAJ / Rezarta DELIBASHZADE, Election Trends 2000-2014, 56

${ }^{69}$ Konrad Adenauer Stiftung, Local elections in Kosovo Final Results, Supplementary Report on the Local Elections 2013 in Kosovo, January 2014, http://www.kas.de/wf/doc/kas 36704-1522-1-30.pdf?140227112431 ${ }^{70}$ Adrian ZEQIRI / Lars BUREMA / Jérémie ZEITOUN, Kosovo Local Elections 2013, 5
} 
Brussels Agreement. This was interpreted by some analysts an example of how Belgradebacked officials could spoil institutional proceedings, ${ }^{71}$ whilst others questioned the willingness of the government to truly integrate Serbs in the north, and argued that the situation could have been avoided. ${ }^{72}$

Majority elite concerns over minority participation in institutions and electoral processes returned to the agenda immediately following the election. Following G.I. Srpska's success, ethnic representation in municipal institutions and the potential for Serb parties to build on these results at future elections, prompted a dispute over the proposed extension of the system of reserved seats for minorities in the Kosovo Assembly. The PDK supported a proposal from all minority community parties to extend the reserved seat system, which was due to run out at the end of the current legislative term, leaving the guaranteed seats for minorities in place. ${ }^{73}$ This was opposed by the main Albanian opposition parties; the LDK denied ever agreeing to support this measure, ${ }^{74}$ and the Deputy Prime Minister Edita Tahiri argued that reserved seats were unnecessary, as "We have been very generous toward minority communities especially towards Serbs". ${ }^{75}$ This discourse of zero-sum resource sharing, and limits to minority accommodation, is a continuation of the pre-election Albanian elite campaign rhetoric, extended from minority participation in the electoral process to ethnic plurality of institutions. Whilst the elections marked a turning point in minority participation, the success of VV in Pristina laid the groundwork for ethnic issues, in particular the reserved seats, minority decentralised institutions and the normalisation process to remain as prominent debates before the scheduled parliamentary elections in 2014 .

\section{Electoral Study: National Elections in Kosovo}

Early parliamentary elections for the 120 seats of the unicameral chamber Kosovo Assembly were held on June 8, 2014, using an open list and proportional representation system across all 38 municipalities. The election was called following the government's failure to form a Kosovo Armed Forces from the current Kosovo Security Forces, as Serb MPs - whose vote was required to pass the legislation as an issue of vital interest to minority communities - refused to vote for the act, unless the reserved seat system of minority representation was re-instated. ${ }^{76}$ This resistance represented both Serbs' opposition to the establishment of such a force, and the mobilization of minorities against the constitutionally-scheduled change into a guaranteed seat

\footnotetext{
${ }^{71}$ Valerie HOPKINS, Serbian Bloc Eyes Real Power in Kosovo, Balkan Insight, 26 May 2014, http://www.balkaninsight.com/en/article/serbian-bloc-eyes-real-power-in-kosovo

${ }_{72}$ Gerard M. GALLUCCI, Kosovo - perhaps the Quint still doesn't understand the North?, 14 January 2014, TransConflict, http://www.transconflict.com/2014/01/kosovo-perhaps-quint-still-doesnt-understand-north-141/

${ }^{73}$ Adrian ZEQIRI / Lars BUREMA / Jérémie ZEITOUN, Kosovo Local Elections 2013, 15-18

${ }^{74}$ UNMIK Headlines, Return of reserved seats were promised to minority communities (Koha), UNMIK Media Monitoring, 23 December 2013, http://media.unmikonline.org/? $\mathrm{p}=31240$

${ }^{75}$ UNMIK Headlines, Tahiri: Reserved seats have reached their end (Lajm), UNMIK Media Monitoring, 23

December 2013, http://media.unmikonline.org/?p=31240

${ }^{76}$ Petrit COLLAKU, Kosovo Faces Polls As MPs Dissolve Parliament, Balkan Insight, 7 May 2014, http://www.balkaninsight.com/en/article/kosovo-leaders-agree-parliament-to-dissolve-on-wednesday 17.02.2015.
} 
system of minority participation in the Assembly, which minority parties feared would reduce the number of seats available to them without the need to compete or reach the $5 \%$ threshold. ${ }^{77}$

The 2014 national polls, such as with the 2013 local elections, held significance for Kosovo's development as a post-communist, multi-ethnic democracy. The June elections marked the first parliamentary polls since the 2008 declaration of independence to be held across the entire territory of Kosovo, ${ }^{78}$ again with voting in the four northern municipalities facilitated by the OSCE on behalf of the CEC, and international pressure on both Pristina and Belgrade to encourage Serb participation. On the $6^{\text {th }}$ of May Kosovo's formal negotiations with the EU on the SAA were concluded, demonstrating the European Commissioner for Enlargement's satisfaction with the conduct of local elections, and Pristina's continued commitment to the normalization dialogue between Kosovo and Serbia, rather than compelling progress in implementing required reforms. ${ }^{79}$ Another similarity with the local elections is that analysis of party campaigns and the main issues under contention is most effectively done by examining the contests for majority and non-majority votes respectively. The reasons for this are twofold; firstly, as with the 2013 campaign, almost all candidates adhered to ethnic cleavage by appealing exclusively to their own linguistic communities; ${ }^{80}$ secondly, the participation of Serb minority parties during the campaign period differed from that of all other political entities.

A significant difference from the local elections was a shift from identity-based campaigns to issue-based platforms by Albanian majority parties. After governing Kosovo with four smaller coalition partners since 2008 , the polls were a chance for voters to hold the incumbent PDK accountable for Kosovo's slow economic growth, high unemployment, and widespread corruption. Aware of this, candidates from all mainstream Albanian parties focused on issues such as investment and job creation, rather than attempting to mobilize the electorate over concerns about Serb minority inclusion. Both the PDK and LDK campaigned on economic platforms, with pledges to stimulate wages, create jobs, and increase social welfare, ${ }^{81}$ and the AAK also raised the endemic spread of corruption under the PDK. ${ }^{82}$

Mobilization along ethnic concerns was not entirely absent, however, as discourses of minorities' roles in Kosovo institutions and ownership of the state by a titular nation still featured in the statements made by Albanian party members prior to the election. The PDK

\footnotetext{
${ }^{77}$ Adrian ZEQIRI / Trim KABASHI / Sanja LAZAREVIC / Gazmen SALIJEVIC, General Elections in Kosovo: A View of the Issues, Challenges and the Political Scene Ahead of Voting on June 8th, Pristina, European Centre for Minority Issues Kosovo, 2014,

${ }^{78}$ European Union Election Observation Mission, Preliminary Statement: Successful Election Day consolidates progress in democracy in Kosovo, 9 June 2014, http://www.eods.eu/library/EUEOM\%20PS\%20KOSOVO\%2009-06-2014_en.pdf

${ }^{79}$ Stefan FULE, EU-Kosovo Formal Negotiations For a Stabilisation and Association Agreement Concluded, speech given at the National Council for European Integration, European Commission, 6 May 2014, http://europa.eu/rapid/press-release_SPEECH-14-358 en.htm?locale=en

${ }^{80}$ European Union Election Observation Mission, Preliminary Statement, 9 June 2014

${ }^{81}$ Arijeta LAJKA, Big Promises, Few Details, in Kosovo Election Campaign, Balkan Insight, 2 June 2014, http://www.balkaninsight.com/en/article/kosovo-parties-long-on-promises-short-on-details; UNMIK Headlines, KAF on the agenda on May 5, LDK does not yield on reserved seats (Lajmi), UNMIK Media Monitoring, 28 April 2014, http://media.unmikonline.org/?p=38767

${ }^{82}$ Krenar GASHI, Kosovo Elections: What We Know So Far, LSEE Research on South Eastern Europe, 10 June 2014, http://blogs.1se.ac.uk/lsee/2014/06/10/kosovo-elections-what-we-know-so-far/
} 
unsuccessfully attempted to convince the LDK and VV to support the extension of reserved minority seats, in exchange for Serb votes for the Kosovo Armed Forces, ${ }^{83}$ and continued to make positive statements regarding minority participation in elections and state security structures. ${ }^{84}$ Once again, this inclusive approach towards minorities were constructed as an act of generosity by the majority, conditioned on behaviour and performance; Kosovo's Minister of European Integration, Bekim Collaku (PDK), stated that 'ultimately, we expect from them [Kosovo Serbs] to be constructive and make on contribution not only to promote the rights of their community, but also help to strengthen Kosovo institutions' ${ }^{85}$

Majority fears over Serb influence in the Kosovo Assembly were also expressed through pre-election opposition to reserved seats for minorities by Albanian opposition parties. The LDK continued their opposition to extending this system, whilst maintaining that the party supported integration of Serbs in Kosovo and the normalization dialogue with Belgrade. ${ }^{86}$ This contradiction is explained by the implicit rationale for the LDK's problem with reserved seats; that following the turnout of Serb voters in the 2013 local elections, Serbs could achieve enough seats in the assembly to give them the deciding vote in the likely negotiations to form a coalition government. Given the PDK's coalition with the minority Serb SLS, and their record of publically supporting minority integration, it was unlikely that the LDK would benefit from an increased number of Serb MPs. Accordingly, VV's concern over the possible post-election coalition was rooted in the long-term belief that Serb MPs would be influenced by Belgrade politicians. They claimed that the Association/Community of Serb Municipalities (A/CSM) was an attempt to achieve a 'Greater Serbia', ${ }^{87}$ also repeating the zero-sum claim that that positive discrimination for minorities was causing discrimination against Albanians in state institutions. ${ }^{88}$

Minority Serb mobilization in 2014 revolved around issues of inclusion and access to representation, with the dissolution of intra-ethnic Serb competition by the formation of a unified Serbian List (Srpska Lista). Having failed to prevent the termination of the reserved seat system, Serb parties' pre-election discontent spilled over into the campaign period. Following the CEC's decision that Kosovo state symbols would appear on all election materials, and that Serbs could not participate in polling station committees south of the Ibar, Serbian List representatives froze election activities and threatened to boycott, arguing that the use of such symbols violated the status-neutrality of the Brussels Agreement. ${ }^{89}$ A last minute

\footnotetext{
${ }^{83}$ UNMIK Headlines, Assembly will not be dismissed without reserved seats (Tribuna), UNMIK Media Monitoring, 29 April 2014, http://media.unmikonline.org/?p=38787

${ }^{84}$ UNMIK Headlines, Elections a good opportunity for integration of communities (Lajm), UNMIK Media Monitoring, 5 June 2014, http://media.unmikonline.org/?p=40593; UNMIK Headlines, Kuci: Elections in June? (Lajm), UNMIK Media Monitoring, 2 May 2014 http://media.unmikonline.org/?p=38951

${ }^{85}$ Valerie HOPKINS, Serbian Bloc Eyes Real Power in Kosovo, Balkan Insight

${ }^{86}$ UNMIK Headlines, Mustafa: Belgrade negotiates with Pristina because it needs EU (Bota Sot), UNMIK Media Monitoring, 5 June 2014, http://media.unmikonline.org/?p=40593

${ }^{87}$ Vetevendosje, Extracts of Albin Kurti speech at The Emerging Democracies Institute, Washington, Vetevendosje News, 1 May 2014, http://www.vetevendosje.org/en/news post/albin-kurti-speech-at-theemerging-democracies-institute-washington/

${ }^{88}$ Vetevendosje, Newsletter from the Movement for SELF-DETERMINATION!, 13 December 2013, http://www.vetevendosje.org/wp-content/uploads/2013/12/Newsletter_Nr.385.pdf

${ }^{89}$ B92, Vucic to Discuss Elections With Kosovo Serbs, B92, 3 June 2014, http://www.b92.net/eng/news/politics.php? yyyy $=2014 \& \mathrm{~mm}=06 \& \mathrm{dd}=03 \&$ nav id $=90553$
} 
intervention from Serbian Prime Minister Aleksander Vucic resolved the stand-off, as he instructed Serbs in Kosovo to vote, stipulating that local mayors could not decide to boycott unless it had previously been agreed with Belgrade..$^{90}$ This statement, and the subsequent resumption of campaign activities by Serbian List in the south, was a further indication that Serb leaders in Kosovo do not simply look to Belgrade for guidance; instead the level of domestic Serb engagement with Kosovo institutions is dictated from outside. Additionally, whilst Serb voters in 2013 were choosing whether or not to endorse the principles of the Brussels agreement and accept the transfer of some competencies from the Serbian state to Kosovo institutions, the dominance of Serbian List, and the control exercised over this party by Belgrade, made the quality of choice in the national elections questionable. ${ }^{91}$

The results of the national elections, far from resolving the Assembly's impasse, led to an unprecedented constitutional and parliamentary crisis which left the country in a political impasse when the parliament did not meet for almost six months. Nevertheless, the conduct of the elections was markedly more successful than the local elections in 2013, without a repeat of the violent incidents in Serb majority municipalities. Turnout for the elections at the national level slightly improved on the previous year's local elections, as turnout across Kosovo averaged $42.63 \%,{ }^{92}$ despite the short campaign period. Once again turnout was lower in the northern municipalities, where the average turnout was $25.97 \%$, compared to the average turnout of $47.05 \%$ in the southern Serb majority municipalities. ${ }^{93}$ This can be attributed to the freeze of campaigning in the north, and their passive participation following the decision not to boycott. Despite the fewer incidents of fraud and voter intimidation across Kosovo, compared to the widespread electoral fraud of the 2010 national polls, citizen confidence in the accuracy of the voter list remained low, particularly due the remaining presence of 500,000 non-residents of Kosovo on this list. ${ }^{94}$

The performance of the main Albanian parties was a minor improvement on the 2010 national elections, with the PDK, LDK, Vetevendosje all wining several more parliamentary seats, and the AAK keeping their existing number of seats. ${ }^{95}$ Initially the PDK were declared the victors, with its pre-election coalition receiving $30.38 \%$ of the vote, ${ }^{96}$ and voter opinion of their previous mandate apparently positive. However, this success was short-lived, as each of the PDK's potential coalition partners, the LDK, AAK and the new NISMA party, formed a majority coalition, in an attempt to prevent the PDK from retaining power. VV offered their position as the third largest party in parliament to this new bloc, and despite their opposition to the constitutional requirement of Serb representatives in the government of Kosovo and

\footnotetext{
${ }^{90}$ Ivana NIKOLIC, Vucic Tells Kosvo Serbs Not to Boycott Election, Balkan Insight, 3 June 2014, http://www.balkaninsight.com/en/article/vucic-calls-serbian-people-to-vote

${ }^{91}$ Joanna HANSON, Kosovo Elections: What We Know So Far, LSEE Research on South Eastern Europe, 10 June 2014, http://blogs.lse.ac.uk/lsee/2014/06/10/kosovo-elections-what-we-know-so-far/

92 General Statistics for Kosovo, Republic of Kosovo Central Election Commission, Pristina 2014, http://www.kqz-ks.org/en/results-2014

${ }^{93}$ Statistics by Municipality, Republic of Kosovo Central Election Commission, Pristina 2014, http://www.kqzks.org/en/results-2014

${ }^{94}$ European Union Electionn Observation Mission, Preliminary Statement, 9 June 2014, 5

${ }^{95}$ Edona PECI, Kosovo Final Results Pave Way for New Govt, Balkan Insight, 26 June 2014, http://www.balkaninsight.com/en/article/election-results-show-few-changes-in-kosovo-political-landscape

${ }^{96}$ General Results, Republic of Kosovo Central Election Commission, Pristina 2014, http://www.kqzks.org/en/results-2014
} 
demands to suspend the Brussels agreement, which would have made their participation in a governing coalition untenable, the offer was accepted. ${ }^{97}$ Subsequent confusion regarding the constitutional stipulations on pre and post-election coalitions, and the competencies of the Constitutional Court and the President in such situations, prevented either bloc from developing a government, or repeating the elections. In December 2014 the PDK and LDK established a grand coalition by achieving a majority with the required inclusion of Serbian List MPs, ${ }^{98}$ thus ending the impasse, and consolidating the representation of Belgradebacked MPs in the government of Kosovo. This post-election politicking was a major test for the effectiveness of institutions, such as the Constitutional Court, to resolve the complexities of a power-sharing system which must guarantee minority participation, and the democratic maturity of political elites in Kosovo.

The performance of Serbian List confirmed minority parties' pre-election concerns they would not achieve more than the guaranteed number of seats under the reserved seats system. Despite the awareness that their acquiescence was necessary to support a governing coalition, they did not present any conditions of electoral reform of the minority seat system. Their cooperation during the coalition-forming process was supported by Belgrade; leader of the Serbian Assembly Milovan Drecan maintained that Serb MPs did not need to recognize the status of Kosovo institutions, 'but they need to be part of them so that they can raise the voice of Kosovo Serbs, prevent discrimination against them, and contribute to the return of all Serb IDPs' ${ }^{99}$ The statement highlights the pragmatic need for minority representation in political institutions and accommodation of the minority by the ethnic majority, but also raises again the influence of the Serbian government over Serbian List MPs. Serb voters' acceptance of the diminished plurality of ethnic parties indicates that rather than being a positive vote for Kosovo institutions, Serb participation in the national elections shows a determination to continue being governed from Belgrade, without damaging Serbia's EU aspirations through the persistence of parallel institutions. Whether Serb participation in Kosovo's subsequent government genuinely represents the needs of the local Serb community, or acts as a destabilizing proxy for Belgrade, remains to be seen. Serb participation in the 2014 elections, and the focus on socio-economic issues by majority parties, indicates that whilst there was a slight move away from the identity based politicking of 2013, the continuation of both majority and minority ethno-political mobilization means that the normalization of electoral politics is still an ongoing process in Kosovo.

\section{Conclusions}

Our paper has discussed the impact of the ethnic cleavage on both the normative and practical support of political agendas, which catapult ethno-political entrepreneurs into office. The principles and practices of democratic accountability of a party and the alternative accountability of parties allowed us to generate a dynamic account of transformations of ethnopolitical agendas in this ethnically divided society over the course of two elections. This was

\footnotetext{
${ }^{97}$ BERTELSMANN STIFTUNG, BTI 2016 - Kosovo Country Report. Gütersloh, 2016), 2-3.

${ }^{98}$ Shiqipe MJEKIQI / Michael GALLAGHER, Electoral Studies 38 (2015): 108

${ }^{99}$ UNMIK Headlines, "Serbian List" agrees to enter into coalition with PDK (Zeri), UNMIK Media Monitoring, 10 June 2014, http://media.unmikonline.org/?p=40896
} 
primarily done through the lens of political parties experiencing, but also causing, those changes by making domestic policy choices explicit in the light of their constituent country, as well as of their external homeland's aspirations to foster closer relationships with the EU during the electoral campaign. We identify the distinctive features of ethno-political mobilization in the form of horizontal-informal intra-ethnic agreements, and vertical-formal competition between different political parties representing distinct ethnic constituencies.

Our overview of electioneering and outcomes of two recent elections in Kosovo provided us with the opportunity to evaluate electorates' perceptions of the proposed set up of democratic institutions and policies put forward by competing ethno-political forces. In democratizing states particularly, electoral cycles provide a clear cut picture of public appreciation of the direction, dynamics and successes in elites' attachment to 'tribal politics'. Alternatively, we have witnessed some preparedness of Albanian and Serb ethno-political entrepreneurs to push through novel political norms, support the newly installed regime and commit to competing political, rather than ethnic agendas.

Until the elections in 2013, the political landscape in Kosovo saw a great deal of ethnopolitical entrepreneurship and the success of ethnically defined parties. Specifically, we have seen the re-election of the leading parties or government led-coalitions, the consolidation of long-time smaller parties into larger political conglomerates, and increasingly the emergence of parties and coalitions representing ethnically heterogeneous electorates. While this trend was observable in the run up to elections of 2013, in this paper we have showed how electoral politics has coped with these changes following the 2014 national Assembly elections.

If anything, the participation of Serb voters in these elections makes it painfully clear that in Kosovo, as in most states, existence of democratic political institutions alone does not make political system a fully functioning democracy. Public support expressed by casting an electoral ballot therefore, has been differentiated into two broad categories: normative and practical. The normative level addresses the principle ideas about the social decision-making process as is mediated through political institutions of the state in whose political life citizens take part. The practical aspect reflects the issues which require correctives in policy, adjustments in the focus of governments, and ultimately parties' profiling.

On the other side of the ballot box, electoral politics force political elites to draw up the balance sheet and identify their goals by outlining policy priorities, and as such challenge the political programs of their competitors, which in the case of Serb ethno-political entrepreneurs, also includes political institutions of the state of Kosovo. In situations where the population is poor, government is weak, and the degree of ethnonational fractionalization is high, electoral politics turn into inter-ethnic contests for control over limited resources for political redistribution of power. In a nutshell, our observed elections have forced voters to decide upon the competency of political representatives to deliver change or ensure stability of provisional political institutions in Kosovo in a way corresponding to expectations of the public casting the ballot. However, the conduct of these elections demonstrates that whilst voters have this decision-making capacity, low turnouts, the presence of fraud, and significant pressure to vote from external actors, all point to electoral politics which still suffer from a deficit of democratic norms and practices. Meanwhile, the limited change of incumbents in elections lauded as 
historic, suggests that accountability of political elites is not the highest priority for voters in Kosovo.

Regarding aspirations for Kosovo to become a member of the EU, stemming from both domestic and European elites, successful conduct of elections is considered a critical step of democracy consolidation on the path to accession. This is entrenched both by the formal accession requirements but also by the conclusions of the EU's Election Observation Mission's reports after both the 2013 and 2014 polls, which emphasized the contribution of the "successful" elections to Kosovo's development as a democracy, whilst simultaneously reporting the intra-ethnic nature of campaigning and incidents which hindered free and fair participation of segments of the electorate..$^{100}$

The ethno-political dynamics of the two elections studied here demonstrate another example of what Agarin and Kordell refer to as post-communist elites' responses to EU requirements for change: namely, that 'form has been confused with content'. ${ }^{101}$ Furthermore, having achieved the basic standard of multi-ethnic, competitive elections across all municipalities in Kosovo, such form has been publically welcomed by representatives of European institutions, regardless of the realities of electoral conduct, and despite official European Commission reports which highlight the need for electoral reform. ${ }^{102}$ The purpose of this paper was not to discuss enlargement fatigue of existing EU member states and Kosovo's prospects of future membership, as this is covered elsewhere by a large tract of literature. Our study of these electoral dynamics, however, further adds to work which is skeptical of the progress for inclusion of minorities in Kosovo's post-conflict institutions and the processes by which these institutions develop. These processes cannot be considered independently of the context of European norm promulgation and practices, and the various ways that domestic entrepreneurs in Kosovo, as within other post-Communist states, have interpreted them.

As Rose, Mishler, and Haerpfer point out, political institutions constitute nothing more than "the hardware" of representative democracy. ${ }^{103}$ To operate, this hardware requires the suitable "software" understandable to and accepted by society it governs. Both the scholarly community and policy circles recognize that what political elites make of democratic institutions and institutional opportunity structure is a key component of such software. The software installation process is incomplete until the matters affecting all voters regardless of their ethnic, social and economic backgrounds are intrinsically linked to stable political institutions. Citizen participation in choosing political representatives to sit in the government that is setting, implementing, and monitoring legal standards, and mediating intergroup conflicts through nascent political institutions, is pivotal. Only when an overwhelming majority of the elected representatives unconditionally supports democratic procedures, plays by the rules of

\footnotetext{
${ }^{100}$ European Union Election Observation Mission, Kosovo Municipal Elections 3 November and 1 December 2013 Final Report, January 2014,

http://www.eods.eu/library/EUEOM\%20FR\%20KOSOVO\%2006.03.2014 en.pdf; European Union Election Observation Mission, Preliminary Statement, 9 June 2014

101 Timofey AGARIN and Karl CORDELL, Minority Rights and Protection in Europe, London, 2016, 2.

102 European Commission, Kosovo 2015 Report, http://ec.europa.eu/enlargement/pdf/key documents/2015/20151110 report kosovo.pdf

${ }^{103}$ Richard Rose, William Mishler, and Christian HAERPFER, Democracy and Its Alternatives: Understanding Post-Communist Societies. Baltimore, 1998.
} 
democratic game and are accountable to all citizens of the state, and not only to the co-ethnics, should we consider the software to be running effectively on the hardware of Kosovo, democratic political institutions. 